\title{
Zinc Nanoparticles at Intercrystallite Sites of $\left(\mathrm{Cu}_{0.5} \mathrm{Tl}_{0.5}\right) \mathrm{Ba}_{2} \mathrm{Ca}_{3} \mathrm{Cu}_{4} \mathrm{O}_{12-\delta}$ Superconductor
}

\author{
Irfan Qasim, ${ }^{1}$ M. Mumtaz, ${ }^{1}$ K. Nadeem, ${ }^{1}$ and S. Qamar Abbas ${ }^{2}$ \\ ${ }^{1}$ Materials Research Laboratory, Department of Physics, Faculty of Basic and Applied Sciences (FBAS), \\ International Islamic University (IIU), Islamabad 44000, Pakistan \\ ${ }^{2}$ Materials Science Lab, Department of Physics, Quaid-i-Azam University, Islamabad 45320, Pakistan
}

Correspondence should be addressed to M. Mumtaz; mmumtaz75@yahoo.com

Received 4 December 2015; Revised 16 February 2016; Accepted 18 February 2016

Academic Editor: Jim Low

Copyright (C) 2016 Irfan Qasim et al. This is an open access article distributed under the Creative Commons Attribution License, which permits unrestricted use, distribution, and reproduction in any medium, provided the original work is properly cited.

\begin{abstract}
We synthesized $(\mathrm{Zn})_{x} /\left(\mathrm{Cu}_{0.5} \mathrm{Tl}_{0.5}\right) \mathrm{Ba}_{2} \mathrm{Ca}_{3} \mathrm{Cu}_{4} \mathrm{O}_{12-\delta}\left\{(\mathrm{Zn})_{x} / \mathrm{CuTl}-1234\right\}(x=0 \sim 3 \mathrm{wt} . \%)$ nanoparticles-superconductor composites by solid-state reaction technique and examined the effects of zinc $(\mathrm{Zn})$ nanoparticles on structural and superconducting properties of CuTl-1234 phase. Unaltered crystal structure of host CuTl-1234 phase confirmed the existence of Zn nanoparticles at intercrystallite sites. We observed an improvement in grains size and intergrains connectivity by healing up the voids after incorporation of $\mathrm{Zn}$ nanoparticles in CuTl-1234 superconductor. Superconducting properties of $(\mathrm{Zn})_{x} / \mathrm{CuTl}-1234$ composites were suppressed for all $\mathrm{Zn}$ nanoparticles concentrations. Suppression of zero resistivity critical temperature $\left\{T_{c}(0)\right\}$ and variation in normal state resistivity $\left\{\rho_{300 \mathrm{~K}}(\Omega-\mathrm{cm})\right\}$ were attributed to reduction of superconducting volume fractions and enhanced scattering cross section of mobile carriers.
\end{abstract}

\section{Introduction}

Intergrains connectivity and pinning potential are very important parameters for the enhancement of superconducting properties of bulk high temperature superconductors (HTSCs) from application point of view. Thus, it is important to engineer additional efficient connectivity enhancers in HTSCs synthesized at ambient pressure. Diverse techniques have been exercised to address these issues but one of the most convenient and effective techniques is the addition of appropriate nanosized structures (i.e., nanoparticles, nanowires, and nanorods) at grain-boundaries of bulk HTSCs. A lot of research works by many research groups were carried out but the addition of most suitable nanosized structures is still preferred for the improvement of superconducting parameters as well as efficient pinning centers. The improvement of superconducting parameters (i.e., $T_{c}$, $H_{c}$, and $J_{c}$ ) by the inclusion of $\mathrm{ZrO}_{2}$ and $\mathrm{ZnO}$ nanoparticles in Gd-123 bulk superconducting matrix was reported [1]. The addition of $\mathrm{ZnO}$ and $\mathrm{Zn}_{0.95} \mathrm{Mn}_{0.05} \mathrm{O}$ nanoparticles in polycrystalline $\mathrm{YBa}_{2} \mathrm{Cu}_{3} \mathrm{O}_{y}$ superconductor has increased the flux pinning strength which was attributed to magnetic interaction of pinning centers via vortices [2]. The inclusion of noble metals ( $\mathrm{Ag}$ and $\mathrm{Au}$ ) nanoparticles has enhanced the intergrains coupling, superconducting volume fraction, and superconducting properties of CuTl-1223 phase $[3,4]$. Lower concentration of $\mathrm{ZnO}$ nanoparticles up to $x=0.8 \mathrm{wt} . \%$ has increased $T_{c}(0)$ and further increase of these nanoparticles concentration suppressed the superconductivity of $\left(\mathrm{Cu}_{0.5} \mathrm{Tl}_{0.25} \mathrm{~Pb}_{0.25}\right) \mathrm{Ba}_{2} \mathrm{Ca}_{2} \mathrm{Cu}_{3} \mathrm{O}_{10-\delta}$ phase [5]. Reduction of porosity and improvement in microhardness were observed after addition of $\mathrm{SnO}_{2}$ nanoparticles in $\left(\mathrm{Cu}_{0.5} \mathrm{Tl}_{0.5}\right)-1223$ superconducting matrix [6].

The suppression of superconducting properties was observed after addition of core shell $\mathrm{Ni} / \mathrm{NiO}$ nanoparticles and $\mathrm{ZnFe}_{2} \mathrm{O}_{4}$ nanoparticles in CuTl-1223 matrix, which was attributed to scattering/pair-breaking of carriers across these magnetic nanoparticles due to spin-interaction $[7,8]$. Metallic nanoparticles (i.e., $\mathrm{Ag}, \mathrm{Zn}$, and $\mathrm{Sn}$ ) in $\mathrm{MgB}_{2}$ superconducting matrix have enhanced $J_{c}$, which was attributed to increased intergrains connectivity [9]. Mechanical and electrical properties of $\left(\mathrm{Cu}_{0.5} \mathrm{Tl}_{0.5}\right)-1223$ superconducting 
phase added with $\mathrm{Fe}_{2} \mathrm{O}_{3}$ nanoparticles were studied and increase in $T_{c}$ was observed with low concentration of these nanoparticles (up to $x=0.2 \mathrm{wt} . \%$ ) followed by systematic decrease with $x>0.2 \mathrm{wt}$.\% [10]. Improvement in $J_{c}$ had been observed after addition of $\mathrm{Al}_{2} \mathrm{O}_{3}$ and $\mathrm{NiFe}_{2} \mathrm{O}_{4}$ nanoparticles in $(\mathrm{Bi}, \mathrm{Pb})-2223$ superconductors, which was attributed to these nanoparticles acting as effective pinning centers [11-13]. The enhancement in superconducting properties of $\mathrm{CuTl}$ based family with the addition of $\mathrm{CaO}_{2}, \mathrm{BaO}$, and $\mathrm{CuO}$ nanoparticles had been already reported $[14,15]$.

We have selected one of the most prominent phases $\quad\left(\mathrm{Cu}_{0.5} \mathrm{Tl}_{0.5}\right) \mathrm{Ba}_{2} \mathrm{Ca}_{3} \mathrm{Cu}_{4} \mathrm{O}_{12-\delta} \quad(\mathrm{CuTl}-1234)$ of $\left(\mathrm{Cu}_{0.5} \mathrm{Tl}_{0.5}\right) \mathrm{Ba}_{2} \mathrm{Ca}_{n-1} \mathrm{Cu}_{n} \mathrm{O}_{2 n+4-\delta}(\mathrm{CuTl}-12(n-1) n), n=2$, $3,4, \ldots$, superconducting family for further investigation. We have investigated the effects of addition of nonmagnetic $3 \mathrm{~d}^{10} \mathrm{Zn}$ metallic nanoparticles on superconducting properties of CuTl-1234 phase. We have successfully inserted Zn nanoparticles in CuTl-1234 matrix and characterized the resultant $(\mathrm{Zn})_{x} / \mathrm{CuTl}-1234$ nanoparticles-superconductor composites by different experimental techniques. The addition of $\mathrm{Zn}$ nanoparticles has changed the superconducting properties of different HTSCs [16-19]. The suppression of zero resistivity critical temperature $T_{c}(R=0)$ with the nano- $\mathrm{Zn}$ addition is pretty surprising but may be understood on the basis of their nonuniform dispersion, pair-breaking, and scattering of charge carriers at grain-boundaries of CuTl1234 phase [20-30]. The reproducibility of $(\mathrm{Zn})_{x} / \mathrm{CuTl}-1234$ nanoparticles-superconductor composites with various concentrations (i.e., $x=0 \sim 3 \mathrm{wt} . \%$ ) was ensured by synthesizing and characterizing these composites again and again.

\section{Experimental Details for Sample Preparation and Characterization}

We prepared $\mathrm{Cu}_{0.5} \mathrm{Ba}_{2} \mathrm{Ca}_{3} \mathrm{Cu}_{4} \mathrm{O}_{12-\delta}$ precursor material from $\mathrm{Ba}\left(\mathrm{NO}_{3}\right)_{2}$ (99.50\%, UNI-Chem), $\mathrm{Ca}\left(\mathrm{NO}_{3}\right)_{2} \cdot 4 \mathrm{H}_{2} \mathrm{O}$ (99\%, Appli Chem), and $\mathrm{Cu}_{2}(\mathrm{CN})_{2} \cdot \mathrm{H}_{2} \mathrm{O}(99 \%, \mathrm{BDH})$ compounds. These compounds were mixed in appropriate ratios and were ground in mortar and pestle for 2 hours. The ground mixture was put into quartz boat and placed in furnace for 24 hours firing at $880^{\circ} \mathrm{C}$. The precursor material was cooled down in furnace to room temperature after 24 hours firing at $880^{\circ} \mathrm{C}$. The fired material was again ground for 1 hour and kept in furnace for second time firing under the same conditions to obtain $\mathrm{Cu}_{0.5} \mathrm{Ba}_{2} \mathrm{Ca}_{3} \mathrm{Cu}_{4} \mathrm{O}_{12-\delta}$ precursor material. $\mathrm{Zn}$ nanoparticles were synthesized by sol-gel method. Initially, one solution of $\mathrm{Zn}(\mathrm{NO})_{3}$ and ethanol was prepared and mixed drop by drop with second solution of citric acid and distilled water in a glass beaker with constant stirring. During the process, ammonia $\left(\mathrm{NH}_{3}\right)$ was added to the final solution to raise the $\mathrm{pH}$ value up to 5 . The solution was then heated at $80^{\circ} \mathrm{C}$ till gel formation. The gel was placed in oven at $110^{\circ} \mathrm{C}$ for 12 hours to dry, which was then ground and annealed at $700^{\circ} \mathrm{C}$ for 4 hours to get the final $\mathrm{Zn}$ nanoparticles. Thallium oxide $\left(\mathrm{TI}_{2} \mathrm{O}_{3}\right)(99 \%, \mathrm{BDH})$ and $\mathrm{Zn}$ nanoparticles of $100 \mathrm{~nm}$ in appropriate ratios were mixed in $\mathrm{Cu}_{0.5} \mathrm{Ba}_{2} \mathrm{Ca}_{3} \mathrm{Cu}_{4} \mathrm{O}_{12-\delta}$ precursor material. The precursor material with $\mathrm{Tl}_{2} \mathrm{O}_{3}$ and $\mathrm{Zn}$ nanoparticles was ground for
1 hour and then pelletized under 3.8 tons $/ \mathrm{cm}^{2}$ pressure. The pellets were enclosed in gold capsules and sintered at $880^{\circ} \mathrm{C}$ for nearly 10 minutes in preheated chamber furnace followed by quenching to room temperature to get the required $(\mathrm{Zn})_{x} /\left(\mathrm{Cu}_{0.5} \mathrm{Tl}_{0.5}\right) \mathrm{Ba}_{2} \mathrm{Ca}_{3} \mathrm{Cu}_{4} \mathrm{O}_{12-\delta}\left\{(\mathrm{Zn})_{x} / \mathrm{CuTl}-\right.$ $1234\}, x=0,0.6,1.2,1.8,2.4$, and $3.0 \mathrm{wt} \%$, nanoparticlessuperconductor composites.

Nanoparticles-superconductor $(\mathrm{Zn})_{x} / \mathrm{CuTl}-1234$ composites samples were characterized thoroughly with different available experimental techniques. The structure and phase purity of the material were determined by XRD scans D/Max IIIC Rigaku with a $\mathrm{CuK}_{\alpha}$ source of wavelength $(1.54056 \AA)$. We measured dc-resistivity and ac-susceptibility of these samples. Scanning electron microscopy (SEM) was carried out for morphology. The phonon modes related to the vibrations of various oxygen atoms in the unit cell were determined by FTIR absorption spectroscopy in wave number range from 400 to $700 \mathrm{~cm}^{-1}$.

\section{Results and Discussions}

XRD pattern exhibits prominent diffraction peaks indexed with hexagonal closed pack (HCP) structure of $\mathrm{Zn}$ nanoparticles as shown in Figure 1. The distinct diffraction peaks at $36.34^{\circ}, 39.06^{\circ}, 43.28^{\circ}, 54.36^{\circ}, 70.1^{\circ}, 70.68^{\circ}$, and $77.04^{\circ}$ diffraction angles correspond to (002), (100), (101), (102), (103), (110), and (004) planes of HCP structure, respectively. HCP structure of $\mathrm{Zn}$ nanoparticles matched with the data base of Joint Committee on Powder Diffraction Standards (JCPDS number 00-004-0784). The size of $\mathrm{Zn}$ nanoparticles was calculated by Debye Sherrer's formula and the average size of these $\mathrm{Zn}$ nanoparticles was about $100 \mathrm{~nm}$. The representative XRD spectra of $(\mathrm{Zn})_{x} / \mathrm{CuTI}-1234$ nanoparticles-superconductor composites with $x=0$ and 3.0 wt.\% are shown in Figure 2. These composites have shown the tetragonal structure following $\mathrm{P} 4 / \mathrm{mmm}$ symmetry with almost the same lattice parameters $a=4.21 \AA$ and $c=$ $18.25 \AA$. Majority of the diffraction peaks correspond to CuTl1234 phase. XRD analysis reveals that the $\mathrm{Zn}$ nanoparticles addition has not affected the crystal structure of CuTl-1234 phase. The nonmagnetic $\mathrm{Zn}$ nanoparticles of $100 \mathrm{~nm}$ size dispersed themselves on the surface of CuTl-1234 grains occupying intercrystallite sites. The slight variation in lattice parameters by the addition of $\mathrm{Zn}$ nanoparticles in CuTl1234 superconducting matrix is mainly due to variation of oxygen contents. Some unindexed peaks of very low intensity are possibly due to presence of impurities and some other superconducting phases. The diffraction peaks were indexed using the computer software MDI-Jade and matched with international center for diffraction data (ICDD) record.

The morphology was examined by SEM micrographs of $(\mathrm{Zn})_{x} / \mathrm{CuTI}-1234$ ( $\left.x=0 \sim 3.0 \mathrm{wt} . \%\right)$ nanoparticles-superconductor composites as shown in Figure 3. The granular nature and porosity of these samples are obvious from these micrographs. There is an improvement in the intergrains connectivity as well as in grains size after the addition of $\mathrm{Zn}$ nanoparticles in CuTI-1234 superconducting matrix. The main issue being faced is the nonuniform distribution 


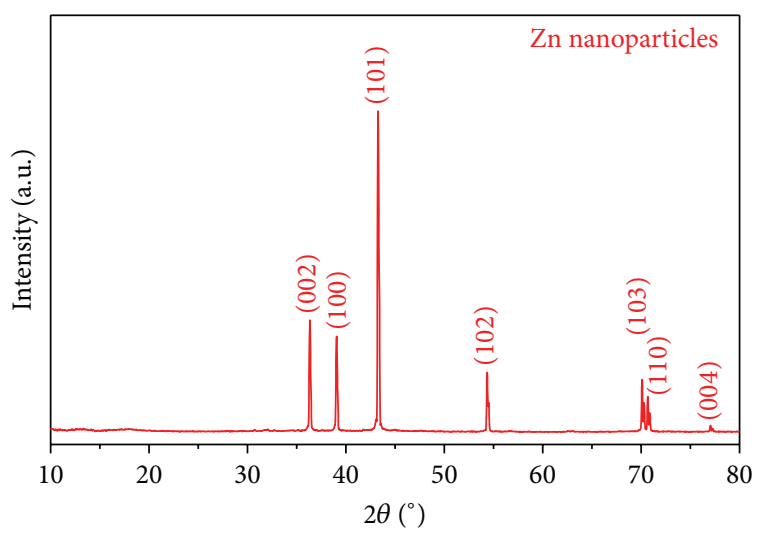

FIGURE 1: XRD pattern of zinc ( $\mathrm{Zn})$ nanoparticles.

of $\mathrm{Zn}$ nanoparticles within the entire bulk CuTI-1234 matrix.

FTIR absorption spectra of $(\mathrm{Zn})_{x} / \mathrm{CuTI}-1234, x=0$, $0.6,1.2,1.8,2.4$, and $3.0 \mathrm{wt} . \%$, nanoparticles-superconductor composites are shown in Figure 4. Considering our previous studies to understand the mechanism of superconductivity in HTSCs, the possibility of electron-phonon interaction cannot be ignored. Oxygen related phonon modes are of special interest, since these modes most likely cause such interactions. We have taken FTIR spectra in the range of $400-700 \mathrm{~cm}^{-1}$ in which the bands from 400 to $540 \mathrm{~cm}^{-1}$ are associated with the apical oxygen atoms and from 541 to $600 \mathrm{~cm}^{-1}$ are associated with $\mathrm{CuO}_{2}$ planar oxygen atoms. The bands from 670 to $700 \mathrm{~cm}^{-1}$ are associated with $\mathrm{O}_{\delta}$ atoms in the charge reservoir layer [31-34]. But in the pure $\mathrm{Cu}_{0.5} \mathrm{Tl}_{0.5} \mathrm{Ba}_{2} \mathrm{Ca}_{3} \mathrm{Cu}_{4} \mathrm{O}_{12-\delta}$ samples, the apical oxygen modes of types $\mathrm{Tl}-\mathrm{O}_{\mathrm{A}}-\mathrm{Cu}(2)$ and $\mathrm{Cu}(1)-\mathrm{O}_{\mathrm{A}}-\mathrm{Cu}(2)$ are observed around $415 \mathrm{~cm}^{-1}$ and $444 \sim 456 \mathrm{~cm}^{-1}$ and $\mathrm{CuO}_{2}$ planner modes are around $541 \mathrm{~cm}^{-1}$. The apical oxygen mode of type $\mathrm{Tl}-\mathrm{O}_{\mathrm{A}}-\mathrm{Cu}(2)$ is slightly hardened to $421 \mathrm{~cm}^{-1}$ and $\mathrm{Cu}(1)-\mathrm{O}_{\mathrm{A}}$ $\mathrm{Cu}(2)$ is softened to $518 \mathrm{~cm}^{-1}$ in nano-Zn particles added samples, which may be due to stresses and strains produced in the material after the addition of these nanoparticles. Almost the positions of all the oxygen vibrational phonon modes remained unaltered after nano-Zn particles addition in CuTl1234 matrix. This gives us a clue that $\mathrm{Zn}$ did not substitute any atom in the unit cell and remained at the grain-boundaries of CuTI-1234 matrix.

The dc-resistivity versus temperature measurements of $(\mathrm{Zn})_{x} / \mathrm{CuTI}-1234, x=0,0.6,1.2,1.8,2.4$, and $3.0 \mathrm{wt} . \%$, nanoparticles-superconductor composites are shown in Figure 5. All the samples exhibit metallic like behavior in variations of dc-resistivity above superconducting transition temperatures. The four-probe method was used for dc-resistivity measurements. Systematic and consistent reduction in $T_{c}$ values from $105 \mathrm{~K}$ for $x=0$ to $93 \mathrm{~K}$ for $x=3.0 \mathrm{wt} . \%$ was observed. The decrease in $T_{c}(0)$ with increasing content of $\mathrm{Zn}$ nanoparticles has been observed as shown in the inset of Figure 5. Gradual decrease in $T_{c}(0)$ with increasing nano- $\mathrm{Zn}$ particles content can be either due to oxygen vacancy disorder or due to mobile carriers

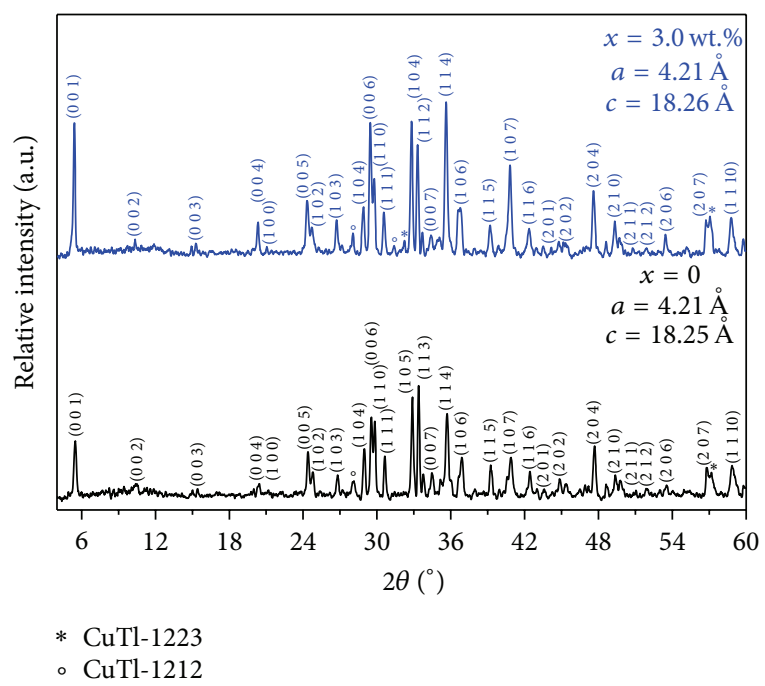

FIGURE 2: XRD patterns of $(\mathrm{Zn})_{x} / \mathrm{CuTl}-1234$ composites with $x=0$ and $3.0 \mathrm{wt} . \%$.

trapping, or due to diminishment of oxygen content in $\mathrm{CuO}_{2}$ conducting planes. Nonmonotonic variation in normal state resistivity $\left\{\rho_{290 \mathrm{~K}}(\Omega-\mathrm{cm})\right\}$ is mainly due to nonuniform distribution of $\mathrm{Zn}$ nanoparticles and irregular scattering of carriers at the grain-boundaries of $(\mathrm{Zn})_{x} / \mathrm{CuTl}-1234$ composite [35-39].

Magnetic ac-susceptibility measurements of $(\mathrm{Zn})_{x} / \mathrm{CuTI}-$ 1234 composites are shown in Figure 6. We used SR530 lockin amplifier working at frequency of $270 \mathrm{~Hz}$ with $H_{\mathrm{AC}}=$ 0.07 Oe of primary coil. There is one peak for all samples above the transition temperatures in all ac-susceptibility measurements for different concentrations of nano-Zn particles in CuTl-1234 superconducting matrix. The magnitude of diamagnetism of the superconducting materials is represented by the real part $\left(\chi^{\prime}\right)$ of ac-susceptibility and the ac-losses corresponding to the flux penetration in the superconducting samples are represented by imaginary part $\left(\chi^{\prime \prime}\right)$. The imaginary part of the ac-susceptibility provides the intergranular contribution, which gives information about the nature of intergrains weak-links and pinning strength $[40,41]$. The suppression of superconductivity within the grains decreases the magnitude of $\chi^{\prime}$. It is observed that onset temperature as well as magnitude of diamagnetism has overall been decreased with increased $\mathrm{Zn}$ nanoparticles content. The peak position in $\chi^{\prime \prime}$ is clearly shifted to lower temperature values with increased $\mathrm{Zn}$ nanoparticles.

The regular decreasing trend in superconducting properties can be expected due to reduction of superconducting volume fraction with increasing content of $\mathrm{Zn}$ nanoparticles at the grains-boundaries of CuTI-1234 superconductor. The second possible reason may be due to enhanced scattering cross section of carriers after addition of nanoparticles of nonmagnetic $3 \mathrm{~d}^{10} \mathrm{Zn}$ element.

\section{Conclusion}

The effects of $\mathrm{Zn}$ nanoparticles addition on superconducting properties as well as phase formation of CuTl-1234 

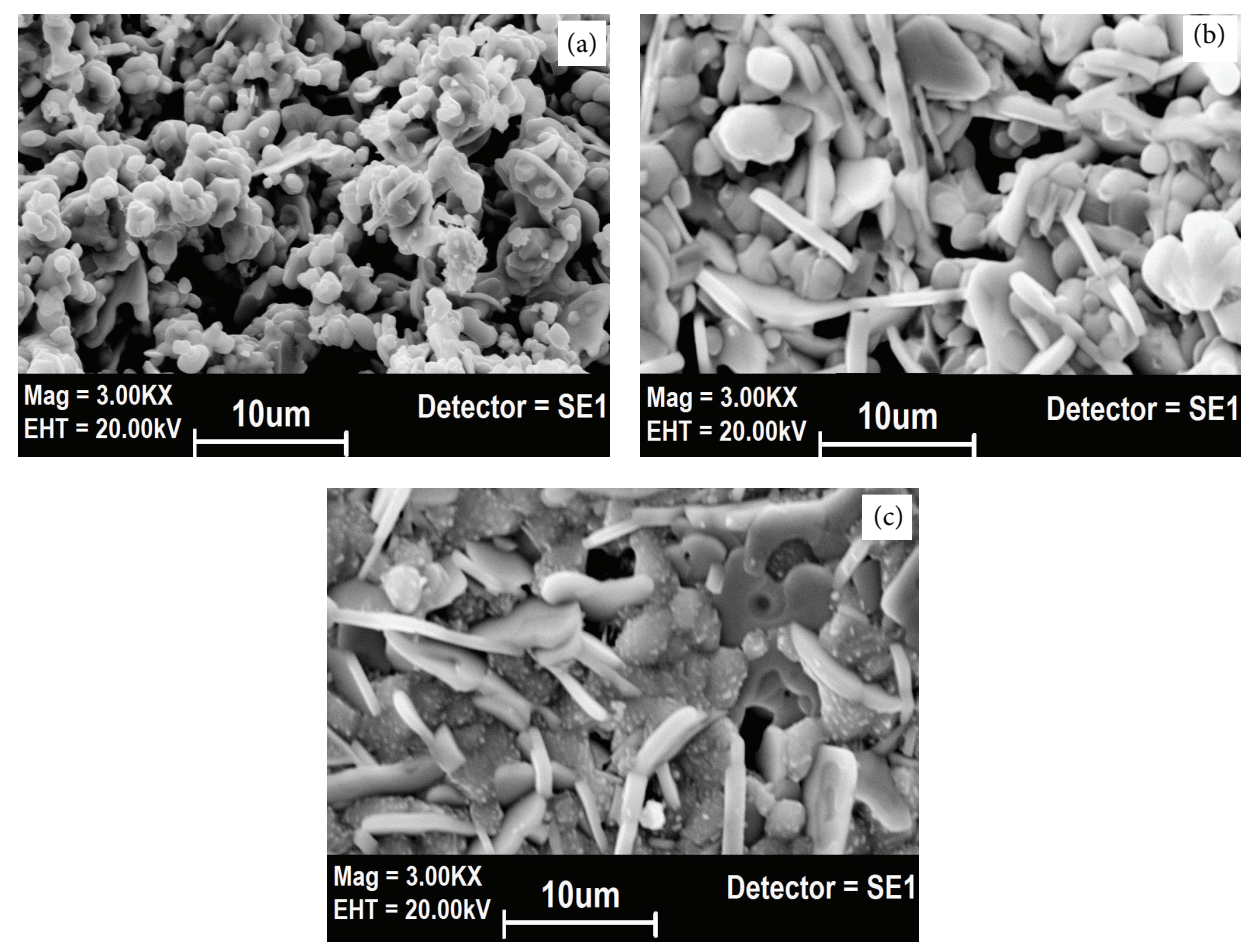

FIgURE 3: SEMs of $(\mathrm{Zn})_{x} / \mathrm{CuTl}-1234$ composites with (a) $x=0$, (b) $x=0.6$, and (c) $x=1.8 \mathrm{wt} . \%$.

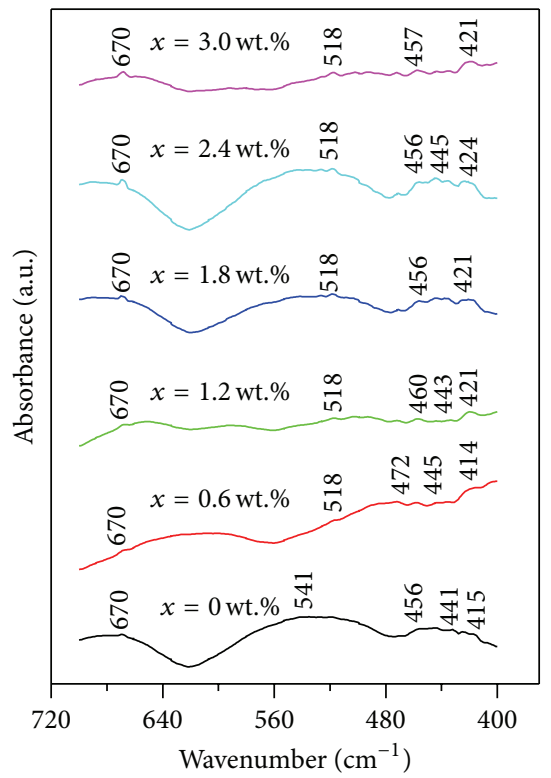

Figure 4: FTIR spectra of $(\mathrm{Zn})_{x} / \mathrm{CuTl}-1234$ composites with $x=0$, $0.6,1.2,1.8,2.4$, and $3.0 \mathrm{wt} . \%$.

superconductor were studied. We synthesized $(\mathrm{Zn})_{x} / \mathrm{CuTI}-$ 1234 composites successfully by well established solid-state reaction. The tetragonal structure of CuTl-1234 phase was determined by XRD, which remained unaltered and uninterrupted after nano-Zn particles addition. Unaltered crystal structure of host CuTl-1234 phase confirmed the existence of $\mathrm{Zn}$ nanoparticles at the intercrystallite sites. The SEM

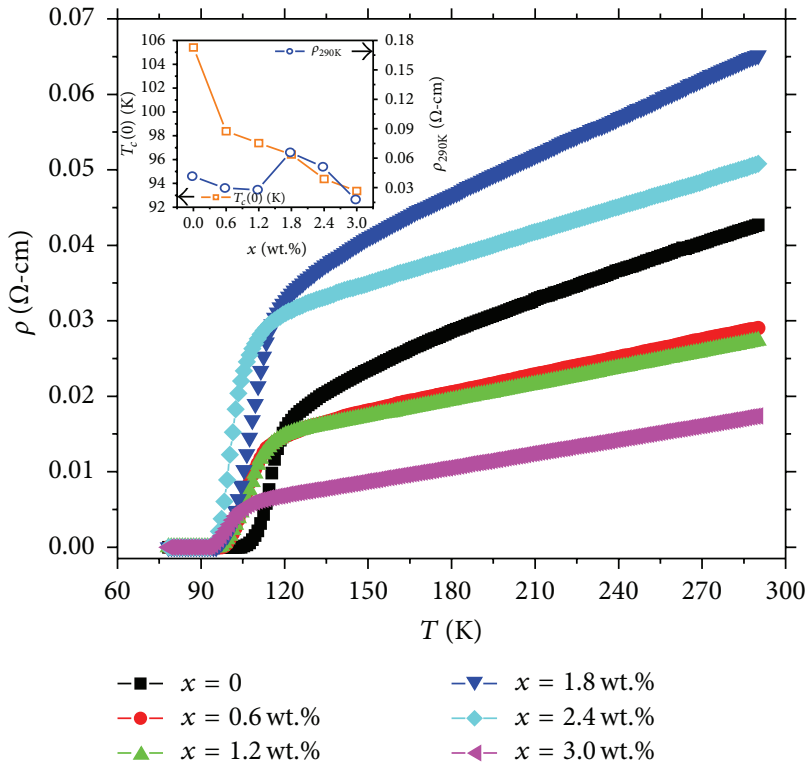

FIGURE 5: Temperature dependence of dc-resistivity measurements of $(\mathrm{Zn})_{x} / \mathrm{CuTl}-1234$ composites with $x=0,0.6,1.2,1.8,2.4$, and $3.0 \mathrm{wt} . \%$.

micrographs have shown the enhanced grain sizes after nano$\mathrm{Zn}$ particles addition. The suppression of superconducting properties of CuTl-1234 phase after addition of nonmagnetic $3 \mathrm{~d}^{10} \mathrm{Zn}$ element nanoparticles can be attributed to reduction of superconducting volume fractions and enhanced scattering cross section of mobile carriers. 


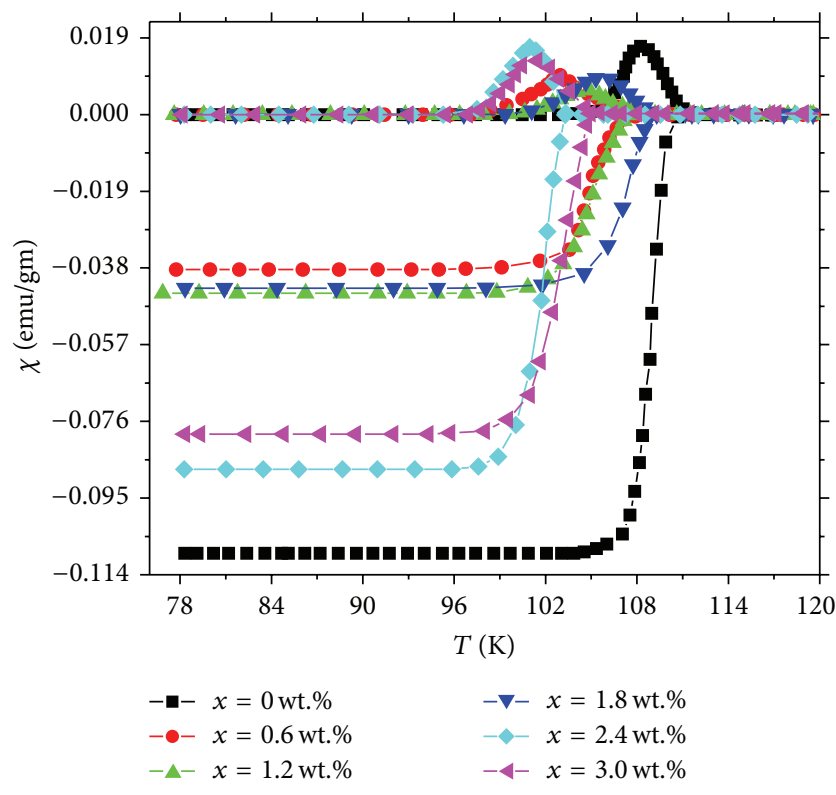

FIGURE 6: AC susceptibility measurements of $(\mathrm{Zn})_{x} / \mathrm{CuTl}-1234$ composites with $x=0,0.6,1.2,1.8,2.4$, and $3.0 \mathrm{wt} . \%$.

\section{Competing Interests}

The authors declare that they have no competing interests.

\section{Acknowledgments}

Higher Education Commission (HEC) of Pakistan is acknowledged for financial supports through Project no. 20-1482/R\&D/09-1472. Authors are also highly thankful to Professor Qiu Xiang-Gang, Beijing National Laboratory of Condensed Matter Physics, Institute of Physics (IOP), Chinese Academy of Sciences (CAS), Beijing, China, for providing the characterization facilities.

\section{References}

[1] Y. Xu, A. Hu, C. Xu, N. Sakai, I. Hirabayashi, and M. Izumi, "Effect of $\mathrm{ZrO}_{2}$ and $\mathrm{ZnO}$ nanoparticles inclusions on superconductive properties of the melt-processed $\mathrm{GdBa}_{2} \mathrm{Cu}_{3} \mathrm{O}_{7-\delta}$ bulk superconductor," Physica C: Superconductivity, vol. 468, no. 1520, pp. 1363-1365, 2008.

[2] M. Annabi, I. Bouchoucha, F. Ben Azzouz, and M. Ben Salem, "Effect of $\mathrm{ZnO}$ and $\mathrm{Zn}_{0,95} \mathrm{Mn}_{0,05} \mathrm{O}$ nano-particle inclusions on YBCO polycrystalline pinning properties," IOP Conference Series: Materials Science and Engineering, vol. 13, no. 1, Article ID 012009, 2010.

[3] W. Abdeen, N. H. Mohammed, R. Awad, S. A. Mahmoud, and M. Hasebbo, "Influence of Nano-Ag addition on phase formation and electrical properties of $\left(\mathrm{Cu}_{0.5} \mathrm{Tl}_{0.5}\right)-1223$ superconducting phase," Journal of Superconductivity and Novel Magnetism, vol. 26, no. 3, pp. 623-631, 2013.

[4] A. Jabbar, M. Mumtaz, and K. Nadeem, "Noble metals (Ag, Au) nanoparticles addition effects on superconducting properties of CuTl-1223 phase," The European Physical Journal Applied Physics, vol. 69, no. 3, Article ID 30601, 2015.
[5] M. M. Elokr, R. Awad, A. Abd El-Ghany, A. Abou Shama, and A. Abd El-Wanis, "Effect of nano-sized $\mathrm{ZnO}$ on the physical properties of $\left(\mathrm{Cu}_{0.5} \mathrm{Tl}_{0.25} \mathrm{~Pb}_{0.25}\right) \mathrm{Ba}_{2} \mathrm{Ca}_{2} \mathrm{Cu}_{3} \mathrm{O}_{10-\delta}$," Journal of Superconductivity and Novel Magnetism, vol. 24, no. 4, pp. 13451352, 2011.

[6] N. H. Mohammed, A. I. Abou-Aly, I. H. Ibrahim, R. Awad, and M. Rekaby, "Mechanical properties of $\left(\mathrm{Cu}_{0.5} \mathrm{Tl}_{0.5}\right)-1223$ added by nano-SnO ${ }_{2}$," Journal of Alloys and Compounds, vol. 486, no. 1-2, pp. 733-737, 2009.

[7] K. Nadeem, F. Naeem, M. Mumtaz et al., "Synthesis and characterization of core-shell $\mathrm{Ni} / \mathrm{NiO}$ nanoparticles/CuTl-1223 superconductor composites," Ceramics International, vol. 40, no. 9, pp. 13819-13825, 2014.

[8] M. Mumtaz, S. Naeem, K. Nadeem et al., "Study of nano-sized $\left(\mathrm{ZnFe}_{2} \mathrm{O}_{4}\right)_{\text {y }}$ particles/CuTl-1223 superconductor composites," Solid State Sciences, vol. 22, pp. 21-26, 2013.

[9] S. Akamaru, F. Ishikawa, K. Nishimura, T. Abe, and M. Matsuyama, "Effects of metal (Ag, Sn and $\mathrm{Zn}$ ) nanoparticles inserted into $\mathrm{MgB}_{2}$ grain boundaries on transport and superconducting properties," Materials Transactions, vol. 54, no. 12, pp. 2258-2264, 2013.

[10] N. H. Mohammed, A. I. Abou-Aly, R. Awad, I. H. Ibrahim, M. Roumié, and M. Rekaby, "Mechanical and electrical properties of $\left(\mathrm{Cu}_{0.5} \mathrm{Tl}_{0.5}\right)-1223$ phase added with nano- $\mathrm{Fe}_{2} \mathrm{O}_{3}$," Journal of Low Temperature Physics, vol. 172, no. 3-4, pp. 234-255, 2013.

[11] M. Annabi, A. M'chirgui, F. Ben Azzouz, M. Zouaoui, and M. Ben Salem, "Addition of nanometer $\mathrm{Al}_{2} \mathrm{O}_{3}$ during the final processing of (Bi, $\mathrm{Pb})-2223$ superconductors," Physica C: Superconductivity, vol. 405, no. 1, pp. 25-33, 2004.

[12] A. Ghattas, M. Annabi, M. Zouaoui, F. Ben Azzouz, and M. Ben Salem, "Flux pinning by Al-based nano particles embedded in polycrystalline (Bi,Pb)-2223 superconductors," Physica C, vol. 468, no. 1, pp. 31-38, 2008.

[13] W. Kong and R. Abd-Shukor, "Enhanced electrical transport properties of nano $\mathrm{NiFe}_{2} \mathrm{O}_{4}$-added $\left(\mathrm{Bi}_{1.6} \mathrm{~Pb}_{0.4}\right) \mathrm{Sr}_{2} \mathrm{Ca}_{2} \mathrm{Cu}_{3} \mathrm{O}_{10}$ superconductor," Journal of Superconductivity and Novel Magnetism, vol. 23, no. 2, pp. 257-263, 2010.

[14] N. A. Khan, A. Saleem, and S. T. Hussain, "Enhanced inter-grain connectivity in nano-particles doped $\left(\mathrm{Cu}_{0.5} \mathrm{Tl}_{0.5}\right) \mathrm{Ba}_{2} \mathrm{Ca}_{2} \mathrm{Cu}_{3} \mathrm{O}_{10-\delta}$ superconductors," Journal of Superconductivity and Novel Magnetism, vol. 25, no. 6, pp. 1725-1733, 2012.

[15] M. Mumtaz, A. I. Bhatti, K. Nadeem, N. A. Khan, A. Saleem, and S. T. Hussain, "Study of $\mathrm{CuO}$ nano-particles/CuTl-1223 superconductor composite," Journal of Low Temperature Physics, vol. 170, no. 3-4, pp. 185-204, 2013.

[16] Y. K. Kuo, C. W. Schneider, M. J. Skove, M. V. Nevitt, G. X. Tessema, and J. J. McGee, "Effect of magnetic and nonmagnetic impurities $(\mathrm{Ni}, \mathrm{Zn})$ substitution for $\mathrm{Cu}$ in $\mathrm{Bi}_{2}(\mathrm{SrCa})_{2+n}\left(\mathrm{Cu}_{1-x} M_{x}\right)_{1+n} \mathrm{O}_{y}$ whiskers," Physical Review B, vol. 56, no. 10, pp. 6201-6206, 1997.

[17] X. Zhang, K. W. Yip, and C. K. Ong, "Zn, Ce, Pr, and Th doping in $\mathrm{YBa}_{2} \mathrm{Cu}_{4} \mathrm{O}_{8}$," Physical Review B, vol. 51, no. 2, pp. 1277-1281, 1995.

[18] Y. Itoh, T. Machi, C. Kasai et al., "Zn-neighbor Cu NQR in Znsubstituted $\mathrm{YBa}_{2} \mathrm{Cu}_{3} \mathrm{O}_{7-\delta}$ and $\mathrm{YBa}_{2} \mathrm{Cu}_{4} \mathrm{O}_{8}$," Physical Review $B$, vol. 67, no. 6, Article ID 064516, 2003.

[19] Y. X. Zhou, S. Scruggs, and K. Salama, "Effects of ionic doping on superconducting properties of melt textured $\mathrm{YBa}_{2}\left(\mathrm{Cu}_{1-x} \mathrm{M}_{x}\right)_{3} \mathrm{O}_{7-\delta}(\mathrm{M}=\mathrm{Co}, \mathrm{Ni}, \mathrm{Zn}$ or $\mathrm{Ga})$ large grains," Superconductor Science and Technology, vol. 19, no. 7, pp. S556-S561, 2006. 
[20] V. N. Vieira, P. Pureur, and J. Schaf, "Effects of $\mathrm{Zn}$ and $\mathrm{Mg}$ in $\mathrm{Cu}$ sites of $\mathrm{YBa}_{2} \mathrm{Cu}_{3} \mathrm{O}_{7-\delta}$ single crystals on the resistive transition, fluctuation conductivity, and magnetic irreversibilities," Physical Review B, vol. 66, Article ID 224506, 2002.

[21] A. Yamamoto, K. Minami, W.-Z. Hu, A. Miyakita, M. Izumi, and S. Tajima, "Effects of $\mathrm{Zn}$ substitution on the superconductivity and pseudogap in $\mathrm{HgBa}_{2} \mathrm{CuO}_{4+\delta}$ with various doping levels," Physical Review B, vol. 65, no. 10, Article ID 104505, 2002.

[22] A. Iyo, Y. Tanaka, M. Hirai, K. Tokiwa, and T. Watanabe, “Zn and $\mathrm{Ni}$ doping effect on anomalous suppression of $\mathrm{T}_{c}$ in an over doped region of $\mathrm{TlBa}_{2} \mathrm{Ca}_{2} \mathrm{Cu}_{3} \mathrm{O}_{9-\delta}$," Journal of Low Temperature Physics, vol. 131, no. 3-4, pp. 643-646, 2003.

[23] I. G. Kaplan, J. Soullard, and J. Hernández-Cobos, "Effect of $\mathrm{Zn}$ and $\mathrm{Ni}$ substitution on the local electronic structure of the $\mathrm{YBa}_{2} \mathrm{Cu}_{3} \mathrm{O}_{7}$ superconductor," Physical Review B, vol. 65, no. 21, Article ID 214509, 7 pages, 2002.

[24] S. H. Pan, E. W. Hudson, K. M. Lang, H. Elsaki, S. Uchida, and J. C. Davis, "Imaging the effects of individual zinc impurity atoms on superconductivity in $\mathrm{Bi}_{2} \mathrm{Sr}_{2} \mathrm{CaCu}_{2} \mathrm{O}_{8+\delta}$," Nature, vol. 403, no. 6771, pp. 746-750, 2000.

[25] Y. Hanaki, Y. Ando, S. Ono, and J. Takeya, "Zn-doping effect on the magnetotransport properties of $\mathrm{Bi}_{2} \mathrm{Sr}_{2-x} \mathrm{La}_{x} \mathrm{CuO}_{6+\delta}$ single crystals," Physical Review B, vol. 64, Article ID 172514, 2001.

[26] T. Kawamata, T. Adachi, T. Noji, and Y. Koike, "Giant suppression of superconductivity at $x=0.21$ in the $\mathrm{Zn}$-substituted $\mathrm{La}_{2-x} \mathrm{Sr}_{x} \mathrm{Cu}_{1-y} \mathrm{Zn}_{y} \mathrm{O}_{4}$ single crystals," Physical Review B, vol. 62, no. 18, Article ID R11981, 2000.

[27] H. Alloul, P. Mendels, H. Casalta, J. F. Marucco, and J. Arabski, "Correlations between magnetic and superconducting properties of $\mathrm{Zn}$-substituted $\mathrm{YBa}_{2} \mathrm{Cu}_{3} \mathrm{O}_{6+x}$," Physical Review Letters, vol. 67 , no. 22, pp. 3140-3143, 1991.

[28] N. Kakinuma, Y. Ono, and Y. Koike, "Anomalies of $T_{c}$, resistivity, and thermoelectric power in the overdoped region of $\mathrm{La}_{2-x} \mathrm{Sr}_{x} \mathrm{Cu}_{1-y} \mathrm{Zn}_{y} \mathrm{O}_{4}$, Physical Review B, vol. 59, no. 2, pp. 1491-1496, 1999.

[29] Y. Fukuzumi, K. Mizuhashi, and S. Uchida, "Zn-doping effect on the $c$-axis charge dynamics of underdoped high-Tc cuprates," Physical Review B, vol. 61, no. 1, pp. 627-633, 2000.

[30] R. Awad, N. S. Aly, I. H. Ibrahim, A. I. Abou-Aly, and A. I. Saad, "Replacement study of Thallium by $\mathrm{Zn}$ and Ni in Tl-1223 superconductor phase," Physica C, vol. 341-348, no. 1, pp. 685$686,2000$.

[31] A. D. Kulkarni, F. W. de Wette, J. Prade, U. Schröder, and W. Kress, "Lattice dynamics of high-Tc superconductors: optical modes of the thallium-based compounds," Physical Review B, vol. 41, no. 10, pp. 6409-6417, 1990.

[32] M. Mumtaz, N. A. Khan, and E. U. Khan, "Growth of $\mathrm{Cu}_{0.5} \mathrm{Tl}_{0.5} \mathrm{Ba}_{2} \mathrm{Ca}_{3} \mathrm{Cu}_{4-y} \mathrm{ZnyO}_{12}$ - $(y=0,1,1.5,2,2.5)$ superconductor with optimum carriers," Physica C, vol. 470, 428, p. 434, 2010.

[33] Abdul Jabbar, I. Qasim, M. Waqee-ur-Rehman, M. Zaman, K. Nadeem, and M. Mumtaz, "Structural and superconducting properties of $\left(\mathrm{Al}_{2} \mathrm{O}_{3}\right)_{y} / \mathrm{CuTl}-1223$ composites," Journal of Electronic Materials, vol. 44, no. 1, pp. 110-116, 2015.

[34] M. Mumtaz, M. Kamran, K. Nadeem et al., "Dielectric properties of $\left(\mathrm{CuO}, \mathrm{CaO}_{2} \text {, and } \mathrm{BaO}\right)_{y} / \mathrm{CuTl}-1223$ composites," Journal of Low Temperature Physics, vol. 39, pp. 806-813, 2013.

[35] E. Brecht, W. W. Schmahl, G. Miehe et al., "Thermal treatment of $\mathrm{YBa}_{2} \mathrm{Cu}_{3-x} \mathrm{AlxO}_{6+\delta}$ single crystals in different atmospheres and neutron-diffraction study of excess oxygen pinned by the Al substituents," Physica C: Superconductivity, vol. 265, no. 1-2, pp. 53-66, 1996.
[36] P. F. Miceli, J. M. Tarascon, L. H. Greene, P. Barboux, F. J. Rotella, and J. D. Jorgensen, "Role of bond lengths in the 90-K superconductor: a neutron powder-diffraction study of $\mathrm{YBa}_{2} \mathrm{Cu}_{3-x} \mathrm{Co}_{x} \mathrm{O}_{7-y}$," Physical Review B, vol.37, no. 10, pp. 59325935, 1988.

[37] V. P. S. Awana, S. K. Malik, W. B. Yelon et al., "Neutron diffraction on $\mathrm{Er}_{1-x} \mathrm{Ca}_{x} \mathrm{Ba}_{2} \mathrm{Cu}_{3} \mathrm{O}_{7-\delta}(0.0 \leq \mathrm{x} \leq 0.3)$ system: possible oxygen vacancies in $\mathrm{Cu}-\mathrm{O}_{2}$ planes," Physica C: Superconductivity, vol. 338, no. 3, pp. 197-204, 2000.

[38] S. Cao, L. Li, F. Liu et al., "Structure and charge transfer correlated with oxygen content for a $\mathrm{Y}_{0.8} \mathrm{Ca}_{0.2} \mathrm{Ba}_{2} \mathrm{Cu}_{3} \mathrm{O}_{y}(y=$ 6.84 - 6.32) system: a positron study," Superconductor Science and Technology, vol. 18, no. 5, pp. 606-610, 2005.

[39] J. C. Zhang, F. Q. Liu, G. S. Cheng et al., "Electron-structure and vacancy properties and Al-substitution dependence of the positron lifetime in y12/3 superconducting ceramics," Physics Letters A, vol. 201, no. 1, pp. 70-76, 1995.

[40] N. A. Khan, M. Mumtaz, A. A. Khurram, and P. Kameli, "AC-susceptibility measurements of $\mathrm{Cu}_{1-x} \mathrm{Tl}_{x} \mathrm{Ba}_{2} \mathrm{Ca}_{3} \mathrm{Cu}_{4} \mathrm{O}_{12-\delta}$ superconductor thin films with different thallium content," Physica C: Superconductivity, vol. 468, no. 3, pp. 233-236, 2008.

[41] R. V. Sarmago, K. L. C. Molina, and L. J. D. Guerra, "A new perspective to AC magnetic susceptibility measurements in an unbalanced mutual inductance bridge," Physica C: Superconductivity, vol. 364-365, pp. 239-242, 2001. 

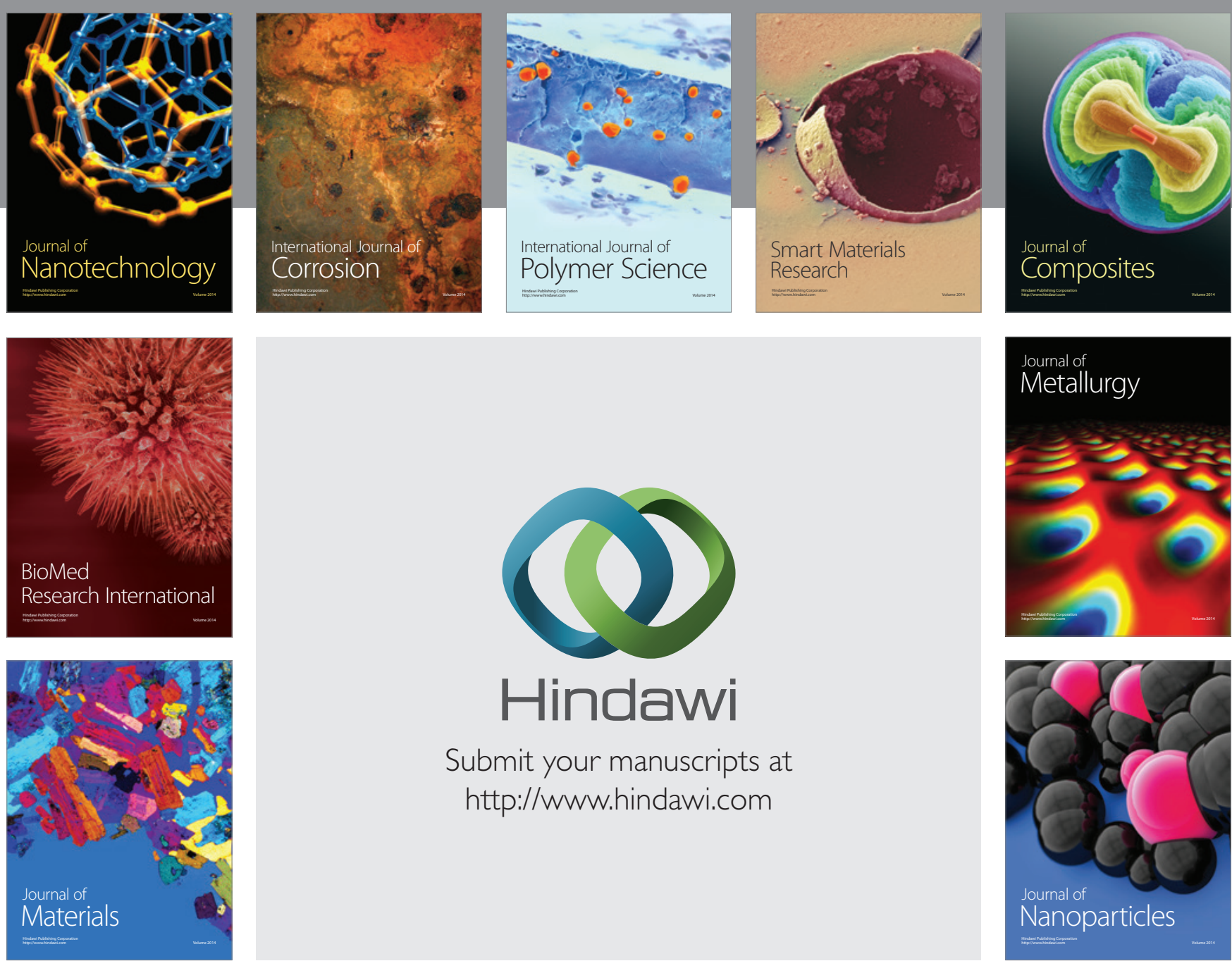

\section{Hindawi}

Submit your manuscripts at

http://www.hindawi.com

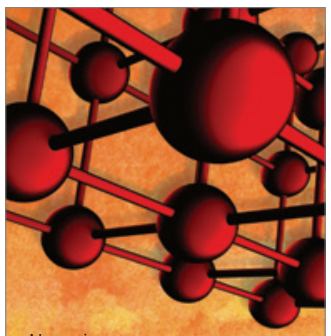

Materials Science and Engineering
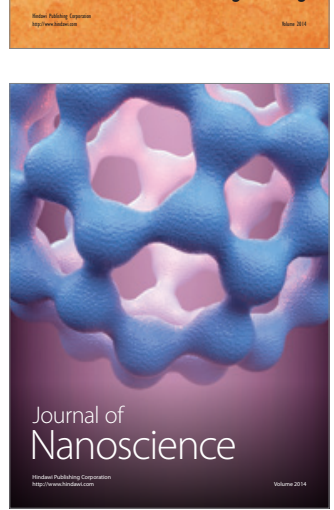
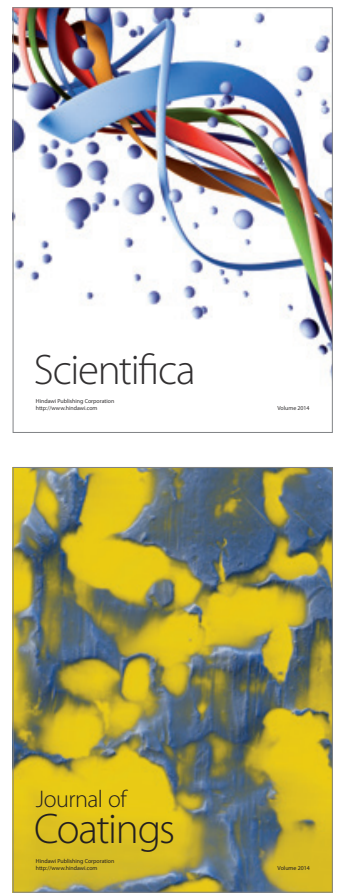
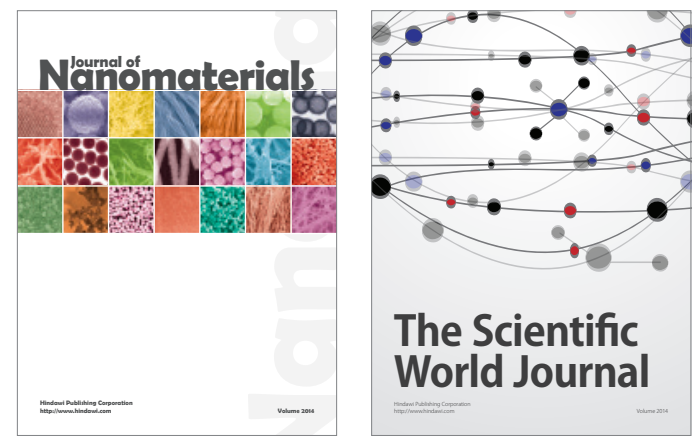

The Scientific World Journal
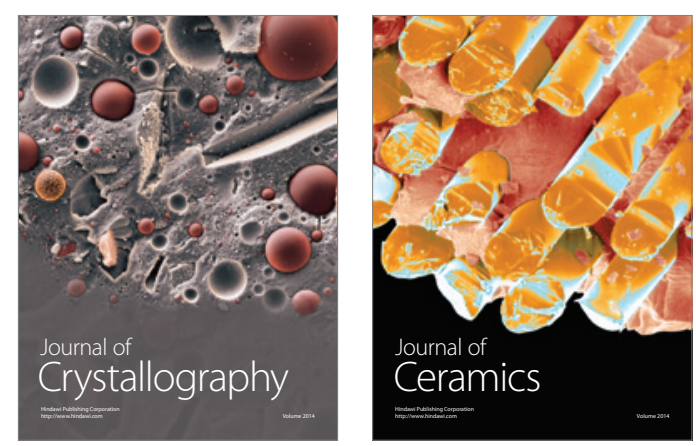
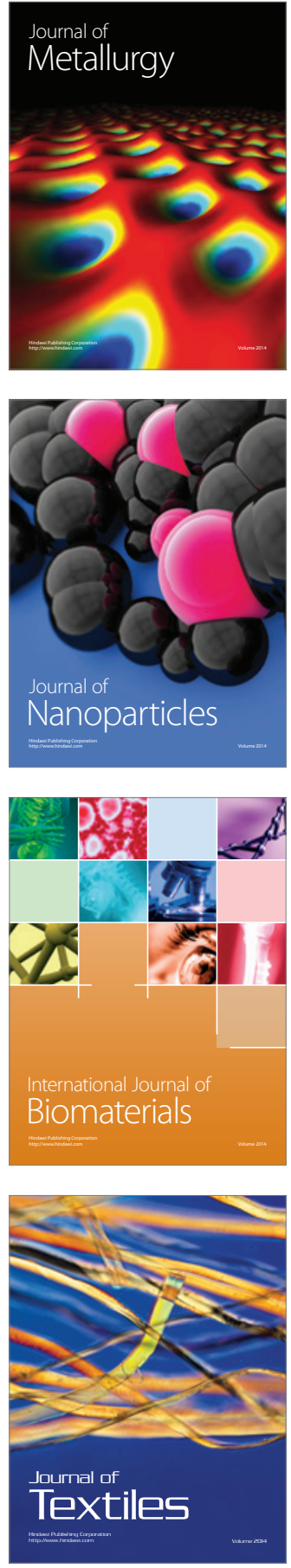